\title{
Melphalan-induced cardiotoxicity: ventricular arrhythmias
}

\author{
U Yanamandra, S Gupta, A Khadwal, P Malhotra
}

Department of Internal Medicine (Clinical Hematology Division), Post Graduate Institute of Medical Education and Research, Chandigarh, India

\section{Correspondence to}

Dr U Yanamandra,

udayj2@gmail.com

Accepted 1 December 2016
CrossMark

To cite: Yanamandra $U$, Gupta S, Khadwal A, et al. BMJ Case Rep Published online: [please include Day Month Year] doi:10.1136/ bcr-2016-218652

\section{DESCRIPTION}

A 61-year-old man, with multiple myeloma (IgA lambda), was planned for autologous stem cell transplantation (ASCT). He also suffered a left thalamic haemorrhagic stroke in 1998 secondary to aneurysmal bleed. Following melphalan infusion of $200 \mathrm{mg}$ at $45 \mathrm{~mL} / \mathrm{min}$, he developed acute onset rhythm abnormalities (intermittent ventricular ectopic and ventricular tachycardia). The patient's premelphalan evaluation was unremarkable with

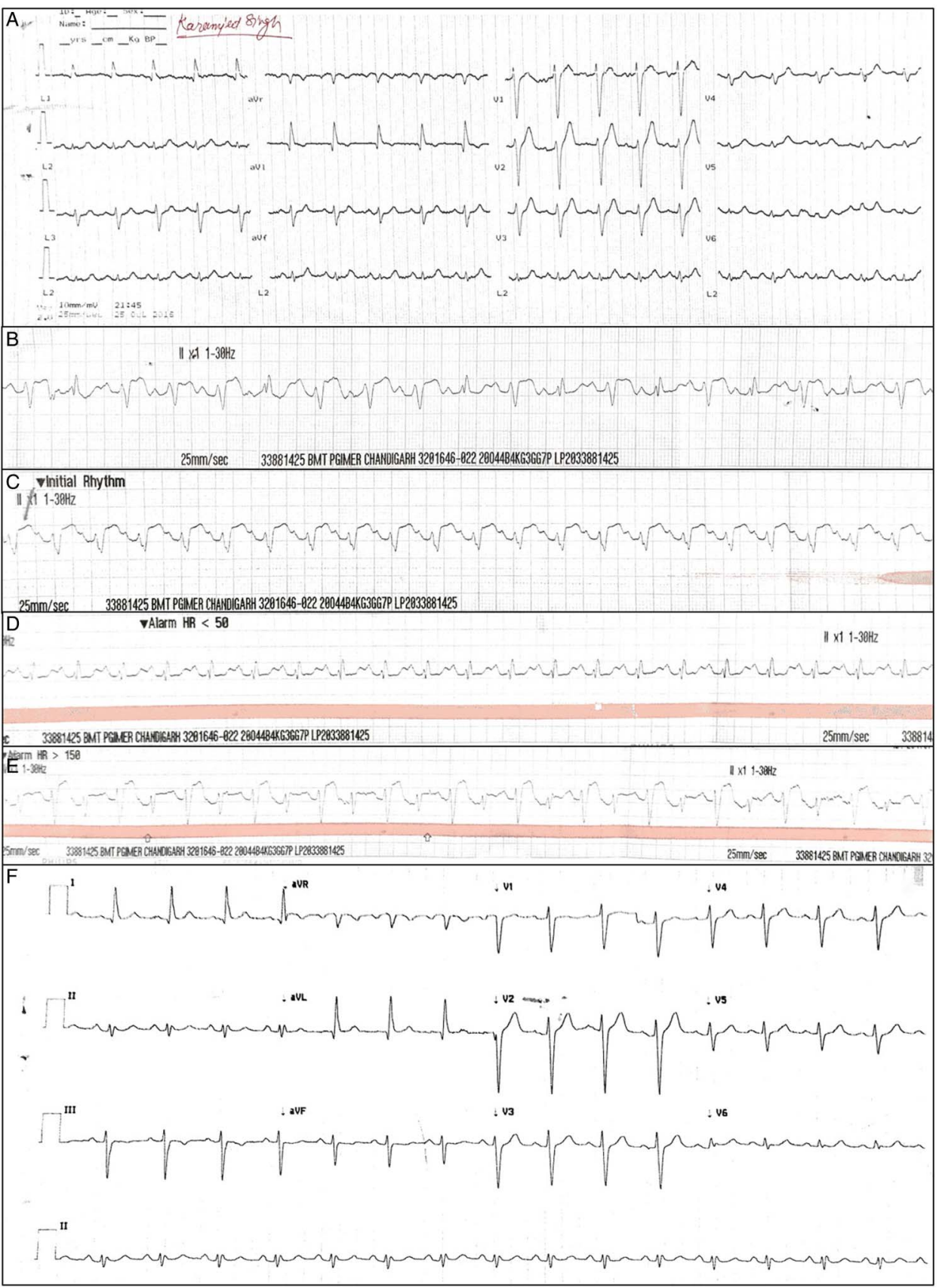

Figure 1 (A) Normal ECG before starting melphalan infusion. (B) ECG after $200 \mathrm{mg}$ of melphalan infusion, showing acute onset ventricular rhythm with atrio-ventricular (AV) dissociation. Subsequent ECG showing dynamic ventricular rhythm at (C) 4 hours (D) 8 hours and (E) 12 hours postinitiation of melphalan infusion. (F) Normalisation of rhythm after 18 hours postinitiation of melphalan infusion. 
normal ECG (1A), ejection fraction $(55 \%)$ and renal/hepatic function. He was evaluated by sequential 2D echocardiography and troponin I (immediately, 2, 4, 12 and 24 hours) which were normal excluding acute STEMI. These rhythm abnormalities were dynamic probably secondary to the plasma melphalan concentrations and normalised by $18 \mathrm{~h}$ postinfusion (figure $1 \mathrm{~B}-\mathrm{F}$ ). There has been no recurrence of these rhythm abnormalities thereafter. He was transplanted with abbreviated melphalan conditioning.

Cardiac toxicity in the form of atrial fibrillation (AF, 6.6$11 \%)$ and supraventricular tachycardia are common after high dose melphalan. ${ }^{1}$ Melphalan is considered the most arrhythmogenic chemotherapeutic agent used in ASCT. ${ }^{1}$ Increased age ( $>60$ years), higher baseline creatinine, larger left atrium size and previous cardiac comorbidities are noted risk factors for

Learning points

- Monitoring for cardiac toxicity in patients receiving high-dose melphalan is mandatory.

- Melphalan should be infused with constant monitoring of rhythm, heart rate, blood pressure and oxygen saturation until four times of the excretion $t_{1 / 2}$ of the drug.

- Patients should be screened for the risk factors for SVT in all patients planned for high-dose melphalan therapy. upraventricular tachycardia (SVT), of which our patient only had age as a risk factor. ${ }^{1}{ }^{2}$ Other conditioning drugs in ASCT with similar cardiotoxicity include cyclophosphamide, anthracyclines and fludarabine. The presence of amyloidosis in multiple myeloma (MM) increases the risk of arrhythmias during ASCT conditioning. Investigators used amifostine to counter cardiac toxicity of increased dose melphalan $\left(\sim 280 \mathrm{mg} / \mathrm{m}^{2}\right) .^{3}$ We present this case due to the rarity of ventricular arrhythmias secondary to melphalan and reversal of normal rhythm chronologically coinciding with excretion $t_{1 / 2}$ of the drug.

Acknowledgements The authors thank Dr Ganesh Kasinadhuni, Cardiology senior resident, for evaluating the case from cardiology department.

Contributors UY, SG, AK and PM involved in the management of the patient. UY involved in the manuscript preparation. All authors vetted the submitted manuscript.

Competing interests None declared.

Patient consent Obtained.

Provenance and peer review Not commissioned; externally peer reviewed.

\section{REFERENCES}

1 Feliz V, Saiyad S, Ramarao SM, et al. Melphalan-induced supraventricular tachycardia: incidence and risk factors. Clin Cardiol 2011;34:356-9.

2 Mileshkin LR, Seymour JF, Wolf MM, et al. Cardiovascular toxicity is increased, but manageable, during high-dose chemotherapy and autologous peripheral blood stem cell transplantation for patients aged 60 years and older. Leuk Lymphoma 2005;46:1575-9.

3 Phillips GL, Meisenberg B, Reece DE, et al. Amifostine and autologous hematopoietic stem cell support of escalating-dose melphalan: a phase I study. Biol Blood Marrow Transplant 2004;10:473-83.

Copyright 2016 BMJ Publishing Group. All rights reserved. For permission to reuse any of this content visit

http://group.bmj.com/group/rights-licensing/permissions.

BMJ Case Report Fellows may re-use this article for personal use and teaching without any further permission.

Become a Fellow of BMJ Case Reports today and you can:

- Submit as many cases as you like

- Enjoy fast sympathetic peer review and rapid publication of accepted articles

- Access all the published articles

- Re-use any of the published material for personal use and teaching without further permission

For information on Institutional Fellowships contact consortiasales@bmjgroup.com

Visit casereports.bmj.com for more articles like this and to become a Fellow 